\title{
Development and evaluation of gastroretentive norfloxacin floating tablets
}

\author{
RAMESH BOMMA ${ }^{1,2}$ \\ RONGALA APPALA SWAMY NAIDU ${ }^{2}$ \\ MADHUSUDAN RAO YAMSANI ${ }^{1}$ \\ KISHAN VEERABRAHMA ${ }^{1 *}$ \\ 1 University College of Pharmaceutical \\ Sciences, Kakatiya University \\ Warangal-506009 (A.P.), India \\ ${ }^{2}$ Natco Pharma Ltd., Kotthur \\ Mahaboobnagar District, India
}

\begin{abstract}
Floating matrix tablets of norfloxacin were developed to prolong gastric residence time, leading to an increase in drug bioavailability. Tablets were prepared by the wet granulation technique, using polymers such as hydroxypropyl methylcellulose (HPMC K4M, HPMC K100M) and xanthan gum. Tablets were evaluated for their physical characteristics, viz., hardness, thickness, friability, and mass variation, drug content and floating properties. Further, tablets were studied for in vitro drug release characteristics for 9 hours. The tablets exhibited controlled and prolonged drug release profiles while floating over the dissolution medium. Non-Fickian diffusion was confirmed as the drug release mechanism from these tablets, indicating that water diffusion and polymer rearrangement played an essential role in drug release. The best formulation (F4) was selected based on in vitro characteristics and was used in vivo radiographic studies by incorporating $\mathrm{BaSO}_{4}$. These studies revealed that the tablets remained in the stomach for $180 \pm 30 \mathrm{~min}$ in fasting human volunteers and indicated that gastric retention time was increased by the floating principle, which was considered desirable for the absorption window drugs.
\end{abstract}

Keywords: norfloxacin, floating tablets, gastric residence time, gastroretentive drug delivery system

Using current release technology, oral delivery for $24 \mathrm{~h}$ is possible for many drugs; however, the substance must be well absorbed throughout the whole gastrointestinal tract. A significant obstacle may arise if there is a narrow window for drug absorption in the gastrointestinal tract (GIT), if a stability problem exists in gastrointestinal fluids, or the drug is poorly soluble in the intestine or acts locally in the stomach. Thus, the real issue in the development of oral controlled release dosage forms is not just to prolong the delivery of the drugs for more than $12 \mathrm{~h}$, but to prolong the presence of the dosage

\footnotetext{
* Correspondence; e-mail: vbkishan@yahoo.com
} 
forms in the stomach or somewhere in the upper intestine until all of the drug is released over the desired period of time (1).

Controlled gastric retention of solid dosage forms may be achieved by the mechanisms of floating systems, swelling and expanding systems, bioadhesive systems, modified shape systems, high density systems or other delayed gastric emptying devices. The principle of buoyant preparation offers a residence time for the dosage form and sustained drug release (2).

The various buoyant preparations include microballoons, granules, powders, capsules, tablets, and laminated films (2). Based on the mechanism of buoyancy, two distinctly different technologies, i.e., non-effervescent and effervescent systems, have been utilized in the development of floating systems. Non-effervescent systems commonly use gel-forming or highly swellable cellulose type hydrocolloids, polysaccharides and matrix forming polymers such as polycarbonate, polyacrylate, polymethacrylate, and polystyrene. Effervescent systems utilize matrices prepared with swellable polymers such as methocel or chitosan and effervescent compounds, e.g., sodium bicarbonate and citric or tartaric acid (3), or matrices containing chambers of liquid that gasify at body temperature (4). Chavampatil et al. (5) have developed the gastroretentive drug delivery system (GRDDS) for ofloxacin with different polymers such as psyllium husk, HPMC K100M, crosspovidone and their combinations in order to get the desired sustained release profile over a period of $24 \mathrm{~h}$. Varshosaz et al. (6) developed ciprofloxacin floating and bioadhesive extended release tablets to increase the duration of the drug presence in its absorption area.

Norfloxacin is a flouroquinolone, broad spectrum antibiotic, and is used in the treatment of urinary tract infections, prostatitis and gonorrhea. Norfloxacin is least absorbed from the lower part of the gastrointestinal tract and is better absorbed from the stomach. This drug has a repetitive dose schedule (400 mg twice daily) (7), short biological half-life $(3-4 \mathrm{~h})(8,9)$ and reduced bioavailability $(30-40 \%)(9)$. Thus, norfloxacin is a candidate for the development of a gastroretentive drug delivery system. In this work, the details of formulation development and evaluation of floating tablets of norfloxacin are described.

\section{EXPERIMENTAL}

\section{Materials}

Norfloxacin was a generous gift sample from Dr. Reddy's Labs, India. Hydroxypropyl methylcellulose (HPMC K4M and HPMC K100M) and xanthan gum were purchased from Colorcon Asia Pvt. Ltd, and Kanwarlal Industries, India, respectively. All other chemicals used were of analytical grade.

\section{Development of tablets}

Accurately weighed quantities (as specified in Table I) of norfloxacin, HPMC K4M, HPMC K100M, xanthan gum and sodium bicarbonate were passed through a $0.425-\mathrm{mm}$ sieve to get uniform size particles, then they were mixed geometrically for 5 to $10 \mathrm{~min}$ - 
Table I. Ingredients $(\mathrm{mg})$ of norfloxacin floating tablets

\begin{tabular}{cccccccc}
\hline Formulation & $\begin{array}{c}\text { HPMC } \\
\text { K4M }\end{array}$ & $\begin{array}{c}\text { HPMC } \\
\text { K100M }\end{array}$ & $\begin{array}{c}\text { Xanthan } \\
\text { gum }\end{array}$ & $\begin{array}{c}\text { Sodium } \\
\text { bicarbonate }\end{array}$ & DCP & PVPK-30 & Lactose \\
\hline F1 & 160 & - & - & 100 & 10 & 15 & - \\
F2 & 140 & - & - & 100 & 20 & 25 & - \\
F3 & 100 & - & - & 100 & 55 & 30 & - \\
F4 & 120 & - & - & 100 & 35 & 30 & - \\
F5 & - & 120 & - & 80 & 5 & 30 & - \\
F6 & - & 100 & - & 80 & 25 & 30 & - \\
F7 & - & 90 & - & 80 & 35 & 30 & - \\
F8 & - & 80 & - & 80 & 45 & 30 & - \\
F9 & - & 70 & - & 80 & 55 & 30 & - \\
F10 & - & - & 140 & 120 & 55 & 20 & - \\
F11 & - & - & 100 & 120 & 95 & 20 & - \\
F12 & - & - & 80 & 120 & 115 & 20 & - \\
F13 & - & - & 80 & 120 & 65 & 20 & 50 \\
F14 & - & - & 100 & 120 & 45 & 20 & 50 \\
F15 & - & - & 140 & 120 & 5 & 20 & 50 \\
F16 & - & - & 130 & 120 & 15 & 20 & 50 \\
\hline
\end{tabular}

All the tablets contain $400 \mathrm{mg}$ norfloxacin, $7 \mathrm{mg}$ magnesium stearate and $8 \mathrm{mg}$ talc.

HPMC - hydroxypropyl methylcellulose, PVP - polyvinyl pyrrolidone, DCP - dicalcium phosphate

utes and the mixture was placed in a polyethylene bag and further mixed for 5 minutes to ensure a homogeneous mass. Accurately weighed quantity of PVPK-30 was dissolved in isopropyl alcohol (IPA) to prepare a binder solution. The binder solution was added to the dry blend gradually with constant kneading to form a homogeneous mass. The dough mass was passed through a $2.0-\mathrm{mm}$ sieve and the granular mass was allowed to dry at room temperature. The granules were passed through a $1.18-\mathrm{mm}$ sieve. These granules were lubricated with magnesium stearate and talc and compressed into tablets using a 16-station punching machine (Rimek, India). The tablets were oblong of $16 \mathrm{~mm}$ length and a thickness of 5.9-6.1 mm.

\section{Characterization of floating tablets}

The prepared floating tablets were evaluated for mass uniformity (20 tablets), hardness ( 6 tablets) was measured by a hardness tester (Erweka tester, Germany), thickness (10 tablets) was measured using a vernier caliperse (Mitutoyo Corporation, Japan) and friability was determined (10 tablets) using a Roche friabilator (Germany).

The drug content in each formulation was determined by triturating 10 tablets and a quantity of powder equivalent to the mass of one tablet was transferred into a $100-\mathrm{mL}$ volumetric flask. To this, $50 \mathrm{~mL}$ of $0.1 \mathrm{~mol} \mathrm{~L}^{-1} \mathrm{HCl}$ was added and then the solution was subjected to sonication for about $2 \mathrm{~h}$. The solution was made up to the mark with 0.1 
mol L ${ }^{-1} \mathrm{HCl}$, filtered and suitable dilutions were prepared with $0.1 \mathrm{~mol} \mathrm{~L}^{-1} \mathrm{HCl}$. The drug content was estimated by recording absorbance at $278 \mathrm{~nm}$ by using a UV-Visible spectrophotometer (Shimadzu U.V. - 2201, Japan).

\section{In vitro buoyancy studies}

The in vitro buoyancy was determined by the floating lag time. The tablets were placed in a $100-\mathrm{mL}$ beaker containing $0.1 \mathrm{~mol} \mathrm{~L}^{-1} \mathrm{HCl}$. The time required for the tablet to rise to the surface for floating was determined as the floating lag time and further floating duration of all tablets was determined by visual observation.

\section{In vitro drug release studies}

The in vitro drug release studies were conducted using the USP 28 type II (10) (paddle) dissolution apparatus (TDT-06T, Electrolab, India). Hydrochloric acid ( $\mathrm{pH} 1.2), 750$ $\mathrm{mL}$, was used as medium. The study was conducted at $37 \pm 0.5{ }^{\circ} \mathrm{C}$ and at paddle rotation of $50 \mathrm{rpm}$. Samples of $5 \mathrm{~mL}$ were collected at predetermined time intervals and replaced with fresh hydrochloric acid. The samples were filtered and diluted and the drug content in the samples was estimated at $278 \mathrm{~nm}$.

Mathematical models, zero-order, first-order, Higuchi and Peppas were applied to analyze the release mechanism and pattern (11-13).

\section{Tablets for in vivo radiographic studies}

Tablets of $6.103 \pm 0.012 \mathrm{~mm}$ thickness and of $700 \pm 4 \mathrm{mg}$ mass were prepared. To make the tablet $\mathrm{X}$-ray opaque, incorporation of $\mathrm{BaSO}_{4}$ was necessary. For this purpose, $100 \mathrm{mg}$ of the drug was replaced with $\mathrm{BaSO}_{4}(100 \mathrm{mg} \mathrm{BaSO} 4+300 \mathrm{mg}$ norfloxacin) and all other ingredients were kept constant. The tablets were characterized for hardness, floating lag time and floating duration.

\section{In vivo radiographic studies}

The protocol of radiographic studies on healthy human volunteers was approved by the Human Ethical Committee, University College of Pharmaceutical Sciences, Kakatiya University, India. The study was conducted on four healthy male volunteers, weighing between $55-75 \mathrm{~kg}$ and in the age group of $25 \pm 2$ years. The tablets prepared for radiography (F4) were administered orally with a glass of water. During the study, the subjects were not allowed to eat but water was available ad libitum. After ingestion of F4 floating tablets containing barium sulphate, the volunteers were exposed to X-ray photography in the abdominal region. The $\mathrm{X}$-ray photographs were taken at $0.5,1.5,3,4$ and $5 \mathrm{~h}$ after administration of the tablets. The mean gastric residence time was calculated. 
RESULTS AND DISCUSSION

\section{Characterization of tablets}

The hardness of formulations F2-F16 was found to be between $8-8.6 \mathrm{~kg} \mathrm{~cm}^{-2}$, except for F1 with hardness of $9.6 \pm 0.2 \mathrm{~kg} \mathrm{~cm}^{-2}$, indicating satisfactory mechanical strength. The thickness of prepared formulations was between 5.9 and $6.1 \mathrm{~mm}$. The friability was in the range of $0.14-0.27 \%$ for all the formulations, which was an indication of good mechanical resistance of the tablet. The average drug content of tablets $(n=10)$ varied between 95.5 and $98.9 \%$, indicating content uniformity of the prepared formulations.

\section{In vitro buoyancy studies}

Norfloxacin tablets were prepared using polymers such as HPMC K4M, HPMC K100M and xanthan gum. Formulations F1-F4, F5-F9 and F10-F16 were prepared with HPMC K4M, HPMC K100M and xanthan gum, respectively. Sodium bicarbonate was added as a gas generating agent. Whitehead et al. (14) have demonstrated good correlation between in vitro and in vivo buoyancy of floating dosage forms. In this study, penetration of water into tablets prepared with xanthan gum was rather slow, causing delayed gel formation and subsequent increase in the floating lag time compared to the tablets prepared with HPMC K4M and HPMC K100M. The best formulation (F4) showed a floating lag time of $35 \pm 4 \mathrm{~s}$, hardness of $8.04 \pm 0.19 \mathrm{~kg}$, thickness of $6.09 \pm 0.01$ $\mathrm{mm}$, friability of $0.21 \%$, content uniformity of $97.3 \pm 0.9 \%$ and mass variation of $700 \pm 3$ mg. Further, it also showed a drug release of $94.3 \pm 1.5 \%$ over $9 \mathrm{~h}$. The floating lag time and duration of floating for the tablets are given in Table II. In general, all the prepared tablets floated for $24 \mathrm{~h}$.

\section{In vitro dissolution studies}

The pharmacokinetic parameters of norfloxacin were used to calculate a theoretical drug release profile for a 12 -h dosage form (15). The in vitro drug release studies revealed that formulations F1, F2 and F4 showed a release of 69.5, 82.1 and $94.3 \%$, respectively, in 9 h (Fig. 1a). Formulation F3 showed maximum drug release of $96.5 \%$ in 8 h. The variation in drug release was due to different polymer concentrations in all the four formulations. The immediate release part for sustained release of norfloxacin was calculated and was found to be $77.8 \mathrm{mg}(19.5 \%)$ of the drug in 1 hour.

It is expected that the developed formulation should have the following theoretical drug release profile, i.e., 20 to $25 \%$ in $1 \mathrm{~h}, 25$ to $45 \%$ in $2 \mathrm{~h}, 55$ to $75 \%$ in $4 \mathrm{~h}, 65$ to $85 \%$ in $6 \mathrm{~h}$ and $85 \%$ after $8 \mathrm{~h}$. Formulations F1-F3 failed to meet the needed theoretical drug release profile. Formulation F4 met the needed theoretical drug release profile and floated with a lag time of $35 \mathrm{~s}$; for these reasons, it was considered the best formulation among all the four formulations of this series.

Formulations F5-F9, composed of HPMC K100M, showed a release of 60.4, 76.0, 83.7, 87.4 and $96.5 \%$ in $9 \mathrm{~h}$, respectively (Fig. 1b). These variations in drug release were due to changes in polymer concentrations of the tablets. However, formulations F5-F8 failed to meet the required theoretical drug release profile. Formulation F9 met the de- 
sired theoretical drug release profile and floated with a lag time of $25 \mathrm{~s}$. It was, therefore, considered the best formulation among all the five formulations of this series.

Drug release profiles of formulations F10-F16, composed of xanthan gum, are shown in Fig. 1c. The percentage of drug released from formulations F10, F11 and F12 was $66.8,74.3$ and 77.3 , respectively, in $9 \mathrm{~h}$. This variation was considered to be due to different polymer concentrations in formulations. Further, these three formulations failed to meet the required theoretical drug release profile. In addition, these formulations showed very long floating lag times. To reduce the floating lag time, lactose was added to the remaining formulations. Formulations F13-F16, composed of xanthan gum and varying ratios of lactose, showed a drug release of $98.6(5 \mathrm{~h}), 96.3(7 \mathrm{~h}), 85.7 \mathrm{(9} \mathrm{h})$ and $93.4(9 \mathrm{~h})$, respectively. Further, formulations F13-F15 failed to meet the needed theoretical drug release profile. However, formulation F16 met the theoretical drug release profile and floated with a lag time of $570 \mathrm{~s}$. Therefore, formulation F16 was considered the best formulation among all the seven formulations of this series. After incorporation of lactose, the drug release was increased due to the capillary action of lactose, which facilitated higher drug release without affecting the matrix. $t_{50}$ (time required for releasing $50 \%$ of the drug) and DE (\%) (dissolution efficiency) are the parameters used to compare the relative efficacy of dosage forms. Decreasing the content of polymers such as HPMC and xanthan gum in tablets, reduced $t_{50}$ but increased the DE (\%) (Table II).

a)

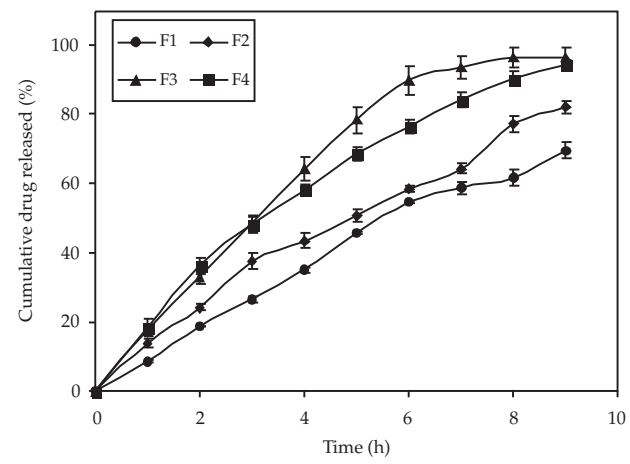

c)

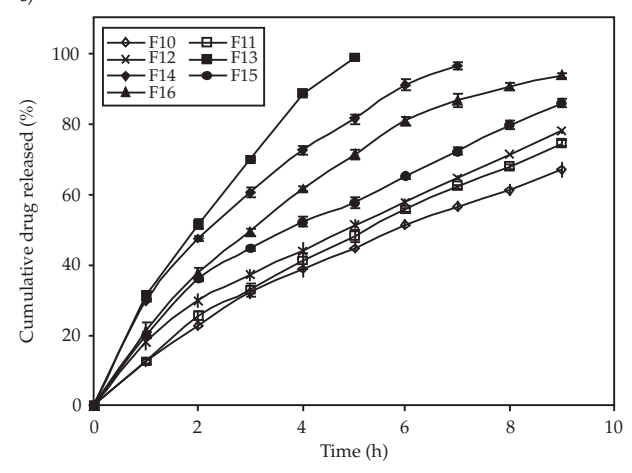

b)

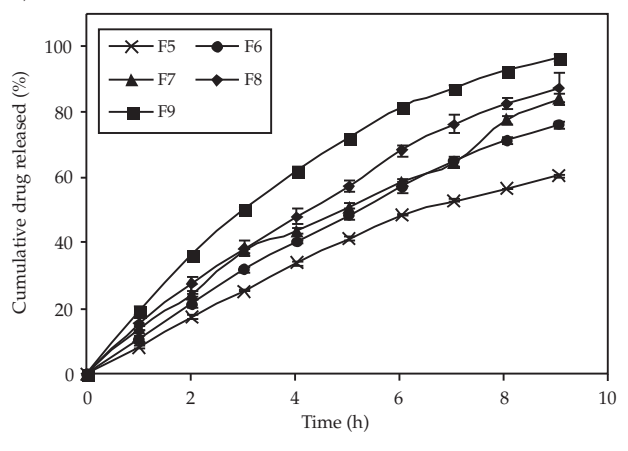

Fig. 1. Drug release profiles of norfloxacin floating tablets prepared with: a) HPMC K4M; b) HPMC K100M and c) xanthan gum (mean $\pm \mathrm{SD}, n=3$ ). 
Table II. Physical properties, dissolution efficiency DE and $\mathrm{t}_{50}$

\begin{tabular}{ccccc}
\hline Formulation & Floating lag time $^{\mathrm{a}}$ & Duration of floating $^{\mathrm{a}}$ & DE $(\%)^{\mathrm{a}}$ & $t_{50}(\mathrm{~h})^{\mathrm{a}}$ \\
\hline F1 & $70 \pm 8$ & $23.65 \pm 0.25$ & $69.7 \pm 0.9$ & $5.46 \pm 0.04$ \\
F2 & $55 \pm 8$ & $24.05 \pm 0.30$ & $82.1 \pm 1.3$ & $4.86 \pm 0.11$ \\
F3 & $60 \pm 4$ & $23.30 \pm 0.22$ & $96.5 \pm 1.2$ & $3.10 \pm 0.07$ \\
F4 & $35 \pm 4$ & $23.45 \pm 0.16$ & $94.3 \pm 1.9$ & $3.16 \pm 0.04$ \\
F5 & $50 \pm 2$ & $24.25 \pm 0.15$ & $60.4 \pm 2.1$ & $6.30 \pm 0.10$ \\
F6 & $35 \pm 1$ & $24.10 \pm 0.35$ & $76.0 \pm 0.7$ & $5.16 \pm 0.02$ \\
F7 & $30 \pm 2$ & $23.35 \pm 0.19$ & $83.7 \pm 2.1$ & $4.88 \pm 0.03$ \\
F8 & $25 \pm 2$ & $24.40 \pm 0.10$ & $87.4 \pm 1.0$ & $4.20 \pm 0.07$ \\
F9 & $25 \pm 2$ & $23.45 \pm 0.20$ & $96.5 \pm 0.8$ & $2.98 \pm 0.18$ \\
F10 & $1860 \pm 29$ & $23.35 \pm 0.27$ & $66.8 \pm 1.8$ & $5.82 \pm 0.18$ \\
F11 & $1500 \pm 24$ & $23.50 \pm 0.26$ & $74.3 \pm 1.2$ & $5.28 \pm 0.04$ \\
F12 & $1380 \pm 16$ & $24.20 \pm 0.19$ & $77.8 \pm 2.4$ & $4.80 \pm 0.18$ \\
F13 & $510 \pm 4$ & $23.37 \pm 0.29$ & $\mathrm{~b}$ & $1.94 \pm 0.19$ \\
F14 & $540 \pm 10$ & $23.40 \pm 0.09$ & $\mathrm{c}$ & $2.22 \pm 0.06$ \\
F15 & $600 \pm 11$ & $23.35 \pm 0.15$ & $85.7 \pm 1.6$ & $3.77 \pm 0.18$ \\
F16 & $570 \pm 4$ & $23.45 \pm 0.12$ & $93.4 \pm 1.6$ & $3.06 \pm 0.09$ \\
\hline
\end{tabular}

a Mean $\pm \mathrm{SD}, n=3$.

b $98.6 \%$ of the drug was released in $5 \mathrm{~h}$.

c $96.3 \%$ of the drug was released in $7 \mathrm{~h}$.

Among several methods investigated for dissolution profile comparison, the f2 factor is the simplest and most applicable. Moore et al. (16) proposed a model independent mathematical approach to compare dissolution profiles using two factors, f1 and f2. FDA (17) has set a public standard of $\mathrm{f} 2$ value between 50 and 100 to indicate similarity between two dissolution profiles. Optimized formulations from each series (F4, F9 and F16) showed similar in vitro drug release profiles to that of the theoretical drug release profile, which was evident from the calculated factors $\mathrm{f} 1$ and $\mathrm{f} 2$ values (F4: $\mathrm{f} 1=7$ and $\mathrm{f} 2=66, \mathrm{~F} 9: \mathrm{f} 1=9$ and $\mathrm{f} 2=63, \mathrm{~F} 16: \mathrm{f} 1=9$ and $\mathrm{f} 2=63)$.

\section{Drug release kinetics}

The tablet containing a polymeric matrix builds, on contact with water, a gel layer around the tablet core, which governs the drug release. It is known that the drug release from HPMC matrices is controlled for water soluble drugs by diffusion through the gel layer or, for poorly soluble drugs, by erosion of the outer polymer chains (18). Hence, the kinetics of swelling is important because the gel barrier is formed with water penetration. The drug release rate kinetics was calculated for zero order, first order and Higuchi models (Table III). 
R. Bomma et al.: Development and evaluation of gastroretentive norfloxacin floating tablets, Acta Pharm. 59 (2009) 211-221.

Table III. Correlation coefficient $\left(\mathrm{R}^{2}\right)$ and release exponent $(\mathrm{n})$ values for different kinetic models

\begin{tabular}{ccccc}
\hline Formulation & Zero-order & First-order & Higuchi & $n$ \\
\hline F 1 & 0.9819 & 0.9887 & 0.9413 & 0.9537 \\
F 2 & 0.9862 & 0.9562 & 0.9578 & 0.7995 \\
F 3 & 0.9321 & 0.9732 & 0.9565 & 0.4596 \\
F 4 & 0.9582 & 0.9683 & 0.9820 & 0.7371 \\
F 5 & 0.9794 & 0.9959 & 0.9808 & 0.916 \\
F 6 & 0.9897 & 0.9927 & 0.9629 & 0.8975 \\
F 7 & 0.9875 & 0.9452 & 0.9552 & 0.803 \\
F 8 & 0.9843 & 0.9790 & 0.9522 & 0.7981 \\
F 9 & 0.9492 & 0.9531 & 0.9628 & 0.7334 \\
F 10 & 0.9743 & 0.9983 & 0.9768 & 0.7547 \\
F 11 & 0.9828 & 0.9910 & 0.9696 & 0.7845 \\
F 12 & 0.9723 & 0.9811 & 0.9832 & 0.6487 \\
F 13 & 0.9766 & 0.8694 & 0.9744 & 0.5464 \\
F 14 & 0.9428 & 0.9428 & 0.9973 & 0.5701 \\
F 15 & 0.9561 & 0.9686 & 0.9892 & 0.6341 \\
F 16 & 0.9421 & 0.9900 & 0.9841 & 0.6828 \\
\hline
\end{tabular}

Drug diffusion through most types of polymeric systems is often best described by Fickian diffusion, but in addition to diffusion, other processes are also important. There is also relaxation of the polymer chains that influences the drug release mechanisms. This process is described as non-Fickian or anomalous diffusion. Release from initially dry, hydrophilic glassy polymers, that swell when added to water and become rubbery, shows anomalous diffusion as a result of the arrangement of macromolecular chains. The thermodynamic state of the polymer and the penetrant concentration are responsible for the different types of diffusion. A third class of diffusion is case II diffusion, which is a special case of non-Fickian diffusion (13). A simple semiempirical equation can be used to analyze data of controlled release of water-soluble drugs from polymer matrices. This equation predicts the mechanism of diffusional release (12):

$$
\frac{M_{t}}{M_{\infty}}=b t^{n}
$$

where $M_{t}$ is the amount of the drug released at time $t, M_{\infty}$ is the overall amount of the drug (whole drug), $b$ is the constant incorporating structural and geometric characteristics of the controlled release device and $n$ is the release exponent indicative of the drug release mechanism. For tablets of a known geometry (in this case a slab) $n=0.5$ means Fickian diffusion, $0.5<n<1.0$ non-Fickian diffusion, and $n=1.0$ case II diffusion (13). Regarding the $n$ values calculated for the studied tablets (Table III), in most cases a non-Fickian mechanism was found to be predominant, which indicated that water diffusion as well as polymer rearrangement played an essential role in drug release. 
The passage of a water-soluble drug through the hydrated gel layer around the matrix tablet is approximately dependent on the square root of time and can be described in the following form (11):

$$
Q_{\mathrm{t}}=k t^{1 / 2}
$$

where $Q_{\mathrm{t}}$ is the amount of the drug released in time $t, k$ is the kinetic constant.

\section{Intra-gastric behavior of floating tablets}

The $\mathrm{BaSO}_{4}$-containing floating tablets showed a floating lag time of $125 \pm 5 \mathrm{~s}$, hardness of $8.16 \pm 0.02 \mathrm{~kg} \mathrm{~cm}^{-2}$ and thickness of $6.103 \pm 0.012 \mathrm{~mm}$. The tablets were clearly seen in the GIT at different positions during the study (Fig. 2). The average residence time was found to be $180 \pm 30 \mathrm{~min}(n=4)$.
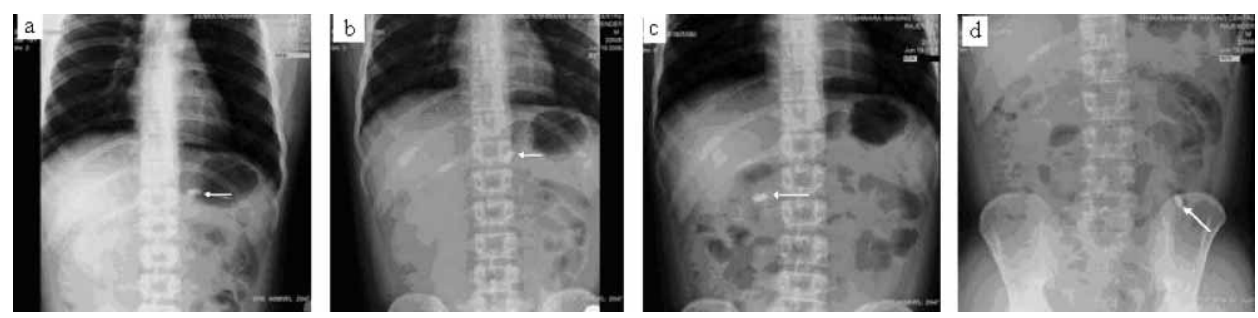

Fig. 2. Radiographic images showing the presence of a $\mathrm{BaSO}_{4}$-loaded floating tablet in the stomach at different time periods (the tablet is indicated with an arrow). The tablet altered its position in the stomach. Images were taken after: a) $0.5 \mathrm{~h}$, b) $1.5 \mathrm{~h}$, c) $3 \mathrm{~h}$, and d) $4 \mathrm{~h}$, after tablet administration.

\section{CONCLUSIONS}

Systematic studies were conducted using three different polymers in different concentrations to prepare norfloxacin floating tablets. Optimized formulations F4 and F9 with HPMC floated with a lag time of less than 1 minute and continued to float for $24 \mathrm{~h}$. Formulation F16, with xanthan gum, floated with a lag time of $9 \mathrm{~min}$ and continued to float for $24 \mathrm{~h}$. Floating lag time of xanthan gum tablets was reduced by using lactose. In vivo radiographic studies revealed that $\mathrm{F} 4$ tablets remained in the stomach for $180 \pm 30$ min, which indicated that GRT was increased by the floating principle and was considered desirable for improving bioavailability of the absorption window drugs.

Acknowledgements. - One of the authors, Mr. Ramesh Bomma, acknowledges the financial support received from AICTE, New Delhi, India. The authors acknowledge M/s Natco Pharma Ltd, Mahaboobnagar District for providing the necessary facilities. 


\section{REFERENCES}

1. S. Baumgartner, J. Kristl, F. Vrecer, P. Vodopivec and B. Zorko, Optimization of floating matrix tablets and evaluation of their gastric residence time, Int. J. Pharm. 195 (2000) 125-135; DOI: 10.1016/S0378-5173(99)00378-6.

2. B. N. Sing and K. H. Kim, Floating drug delivery systems: an approach to oral controlled drug delivery via gastric retention, J. Control. Rel. 63 (2000) 235-259; DOI: 10.1016/S0168-3659(99)00204-7.

3. A. Rubinstein and D. R. Friend, Specific Delivery to the Gastrointestinal Tract, in Polymeric Site-Specific Pharmacotherapy (Ed. A. J. Domb), Wiley, Chichester 1994, pp. 283-285.

4. W. A. Ritschel, Targeting in the gastrointestinal tract: new approaches, Methods Find, Exp. Clin. Pharmacol. 13 (1991) 313-316.

5. C. Mahesh, J. Paras, C. Sachin, S. Rajesh and V. Pradeep, Development of sustained release gastroretentive drug delivery system for ofloxacin: in vitro and in vivo evaluation, Int. J. Pharm. 304 (2005) 178-184; DOI: 10.1016/j.ijpharm.2005.08.009.

6. J. Varshosaz, N. Tavakoli and F. Roozbahani, Formulation and in vitro characterization of ciprofloxacin floating and bioadhesive extended-release tablets, Drug Del. 13 (2006) 277-285; DOI: $10.1080 / 10717540500395106$.

7. K. M. Gerald, Norfloxacin, in AHFS Drug Information, The American Society of Health System Pharmacists, Bethesda 2004, pp. 396-402.

8. C. Mazuel, Norfloxacin, in Analytical Profiles of Drug Substances (Ed. K. Florey), Vol. 20, Academic Press, San Diego 1991, pp. 557-600.

9. Noroxin tablets, in Physician Desk Reference, 61 ${ }^{\text {st }}$ ed., Thomson PDR, Montvale 2007, pp. 2032-2038.

10. United States Pharmacopeia 28, National Formulary 23, USP Convention, Rockville 2005, pp. 2745.

11. T. Higuchi, Rate of release of medicaments from ointment bases containing drugs in suspensions, J. Pharm. Sci. 50 (1961) 874-875.

12. R. W. Korsmeyer, R. Gurny, E. Doelker, P. Buri and N. A. Peppas, Mechanisms of solute release from porous hydrophilic polymers, Int. J. Pharm. 15 (1983) 25-35; DOI: 10.1016/0378-5173(83)90064-9.

13. N. A. Peppas, Analysis of Fickian and non-Fickian drug release from polymers, Pharm. Acta Helv. 60 (1985) 110-111.

14. L. Whitehead, J. T. Fell, J. H. Collett, H. L. Sharma and A. M. Smith, Floating dosage forms: an in vivo study demonstrating prolonged gastric retention, J. Control. Rel. 55 (1998) 3-12; DOI: 10.1016/S0168-3659(97)00266-6.

15. C. S. L. Chiao and J. R. Robinson, Sustained-release Drug Delivery Systems, in Remington: The Sci-

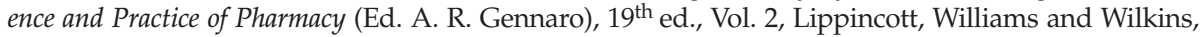
Philadelphia 2000, pp. 1660-1675.

16. J. W. Moore and H. H. Flanner, Mathematical comparison of curves with an emphasis on in vitro dissolution profiles, Pharm. Technol. 20 (1996) 64-74.

17. Guidance for Industry (Dissolution Testing of Immediate Release Solid Oral Dosage Forms), US Department of Health and Human Services, Food and Drug Administration, Center for Drug Evaluation Research (CDER), Aug 1997, pp. 9; www.fda.gov/cder/guidance.htm; access date April 22, 2009.

18. K. Mitchell, J. L. Ford and D. J. Armstrong, The influence of concentration on the release of drugs from gels and matrices containing Methocel, Int. J. Pharm. 100 (1993) 155-163; DOI: 10.1016/ 0378-5173(93)90086-U. 


\section{Razvoj i vrednovanje plutajućih tableta norfloksacina s produljenim zadržavanjem u želucu}

RAMESH BOMMA, RONGALA APPALA SWAMY NAIDU, MADHUSUDAN RAO YAMSANI i KISHAN VEERABRAHMA

Razvijene su plutajuće tablete norfloksacina koje se produljeno zadržavaju u želucu i time povećavaju bioraspoloživost. Tablete su pripravljene metodom vlažne granulacije, koristeći hidroksipropil metilcelulozu (HPMC K4M, HPMC K100M) i ksantan gumu. Tabletama su određena fizikalna svojstva (čvrstoća, debljina, lomljivost i varijacija mase) te sadržaj ljekovite tvari i plutajuća svojstva. Nadalje, praćeno je oslobađanje ljekovite tvari in vitro tijekom $9 \mathrm{~h}$. Uočeno je da je oslobađanje kontrolirano i produljeno te da tablete plutaju u ispitivanom mediju. Mehanizam oslobađanja nije slijedio Fickov zakon, što ukazuje da difuzija vode i promjene u strukturi polimera imaju bitnu ulogu u oslobađanju ljekovite tvari. Najbolja formulacija (F4) in vitro uporabljena je za izradu pripravaka barijevog sulfata za radiografska ispitivanja in vivo. Ispitivanja na volonterima koji su apstinirali od hrane pokazala su da primjena plutajućih tableta produljuje vrijeme zadržavanja u želucu na $180 \pm 30$ min.

Ključne riječi: norfloksacin, plutajuće tablete, vrijeme zadržavanja u želucu, sustav za isporuku lijeka s produljenim zadržavanjem u želucu 